\title{
Factors associated with intramammary infection in dairy cows caused by coagulase-negative staphylococci, Staphylococcus aureus, Streptococcus uberis, Streptococcus dysgalactiae, Corynebacterium bovis, or Escherichia coli
}

\section{S. Taponen, ${ }^{* 1}$ E. Liski, $†$ A.-M. Heikkilä, $†$ and S. Pyörälä*}

${ }^{*}$ Department of Production Animal Medicine, Faculty of Veterinary Medicine, University of Helsinki, Paroninkula 20, Fl-04920 Saarentaus, Finland †Natural Resources Institute Finland, Viikinkaari 4, FI-00790 Helsinki, Finland

\begin{abstract}
The aim of this study was to determine risk factors for bovine intramammary infection (IMI) associated with the most common bacterial species in Finland. Large databases of the Finnish milk-recording system and results of microbiological analyses of mastitic milk samples from Valio Ltd. (Helsinki, Finland) were analyzed. The study group comprised 29,969 cows with IMI from 4,173 dairy herds. A cow with a quarter milk sample in which DNA of target species was detected in the PathoProof Mastitis PCR Assay (Thermo Fisher Scientific, Waltham, MA) was determined to have IMI. Only cows with IMI caused by the 6 most common pathogens or groups of pathogens, coagulase-negative staphylococci (CNS), Staphylococcus aureus, Streptococcus uberis, Streptococcus dysgalactiae, Corynebacterium bovis, and Escherichia coli, were included. The control group comprised 160,176 IMI-free cows from the same herds as the study group. A multilevel logistic regression model was used to study herd- and cow-specific risk factors for incidence of IMI. Pathogen-specific results confirmed those of earlier studies, specifically that increasing parity increases prevalence of IMI regardless of causative pathogen. Holsteins were more susceptible to IMI than Nordic Reds except when the causative pathogen was CNS. Occurrence of IMI caused by $C$. bovis was not related to milk yield, in contrast to IMI caused by all other pathogens investigated. Organic milk production was associated with IMI only when the causative pathogen of IMI was Staph. aureus; Staph. aureus IMI was more likely to occur in conventional than in organic production. Cows in older freestall
\end{abstract}

Received May 16, 2016.

Accepted August 24, 2016.

${ }^{1}$ Corresponding author: suvi.taponen@helsinki.fi barns with parlor milking had an increased probability of contracting an IMI compared with cows in tiestall barns or in new freestall barns with automatic milking. This was the case for all IMI, except those caused by CNS, the prevalence of which was not associated with the milking system, and IMI caused by Staph. aureus, which was most common in cows housed in tiestall barns. A better breeding index for milk somatic cell count was associated with decreased occurrence of IMI, indicating that breeding for improved udder health has been successful in reducing the incidence of IMI caused by the most common pathogens in Finland. In the Finnish dairy sector, the importance of other measures to control IMI will increase as the Holstein breed progressively takes the place of the Nordic Red breed. Attention should be paid to hygiene and cleanliness, especially in old freestall barns. Based on our results, the increasing prevalence of automatic milking is not a reason for special concern.

Key words: dairy cow, bovine mastitis, pathogen, risk factor, polymerase chain reaction assay

\section{INTRODUCTION}

Mastitis is the most common and costly disease of dairy cows. It affects cow welfare and causes economic losses through decreased milk production, reduced milk quality, premature culling, veterinary treatments, and milk discarded due to antibiotic treatments (Halasa et al., 2007; Oltenacu and Broom, 2010; Heikkilä et al., 2012). Clinical mastitis is only a small fraction of the problem, with subclinical mastitis being far more common (Koivula et al., 2007; Olde Riekerink et al., 2008; van den Borne et al., 2010). Incidence and prevalence of mastitis vary among countries and herds (Olde Riekerink et al., 2008; van den Borne et al., 2010; SantmanBerends et al., 2015).

Mastitis results from IMI caused mainly by bacteria. The most common causes of clinical mastitis are 
the major pathogens Escherichia coli (Bradley et al., 2007; Olde Riekerink et al., 2008; Breen et al., 2009), Staphylococcus aureus (Barkema et al., 1999; Reksen et al., 2006; Olde Riekerink et al., 2008), and streptococcal species, especially Streptococcus uberis (McDougall, 1998; Koivula et al., 2007; Olde Riekerink et al., 2008; Levison et al., 2016). Coagulase-negative staphylococci also cause clinical mastitis (Koivula et al., 2007; Olde Riekerink et al., 2008; Levison et al., 2016). Subclinical mastitis is often caused by minor pathogens, including CNS and Corynebacterium bovis, although major pathogens, especially Staph. aureus, also cause subclinical mastitis (Barkema et al., 2006; Koivula et al., 2007). Distribution of the most common species varies among countries and herds, and is apparently linked with management practices and environmental factors in particular countries and herds (Barkema et al., 1999; Milne et al., 2002; Bradley et al., 2007; Olde Riekerink et al., 2008).

Risk factors for mastitis, and high milk SCC in general, have been thoroughly investigated (Barkema et al., 1999; Peeler et al., 2000; Breen et al., 2009; Dufour et al., 2011; Santman-Berends et al., 2015); studies on pathogen-specific risk factors are less common. Selected cow-specific risk factors were recognized for IMI caused by Staph. aureus, Strep. uberis, Strep. dysgalactiae, and CNS (Zadoks et al., 2001; Breen et al., 2009; Ericsson Unnerstad et al., 2009; Sampimon et al., 2009). Management-related herd factors, such as milking technique, production type, nutrition, and hygiene standards, were associated with differences in distributions of mastitis-causing bacteria in the herds (Barkema et al., 1999; Dufour et al., 2011; Piepers et al., 2011; Levison et al., 2016).

For efficient control and treatment of mastitis, the causative agents of IMI in dairy herds need to be known. To provide this information, aseptic milk samples should be taken from infected cows for microbiological analysis. In Finland, it is routine to take milk samples from mastitic quarters; the laboratory of Valio Ltd. (Helsinki, Finland) analyzes most of the samples. At the beginning of 2010, the Valio laboratory switched from conventional culturing to use of a PCR test (PathoProof Mastitis PCR Assay, Thermo Fisher Scientific, Waltham, MA). The semiquantitative realtime PCR assay targets the DNA of 15 microbial species, or groups of species, and the staphylococcal blaZ gene coding for penicillin resistance by $\beta$-lactamase production.

In Finland, $74 \%$ of dairy herds and $81 \%$ of dairy cows are included in the Finnish milk-recording system (ProAgria, 2016). The database includes information on individual cows, feeding, and production environ- ment. Milk yields and milk SCC are recorded every second, fourth, sixth, or eighth week depending on the monitoring agreement of the producer. In addition, disease records of all Finnish dairy cows are registered with the Finnish cattle health-monitoring system. The records are used by farmers, researchers, advisory services, and breeding organizations. Our aim was to use the large databases of the Finnish dairy herd-recording systems and the results of microbiological analyses of quarter milk samples from mastitic cows to study possible links between cow- and herd-specific factors and the occurrence of pathogen-specific IMI.

\section{MATERIALS AND METHODS}

\section{Data}

The data used in our study comprise microbiological diagnoses of quarter milk samples from mastitic cows analyzed with the PathoProof Mastitis PCR Assay and data from the Finnish milk-recording system, the Finnish cattle health-monitoring system, and the database of Faba, the co-operative cattle breeding organization in Finland. The data were used to divide cows into a study group and a control group. All cows from the herds that sent milk samples to the laboratory of Valio Ltd. during 2012 for microbiological analysis and belonged to the national milk-recording system were included in the preliminary data.

The original study group, 45,582 cows, consisted of cows that had at least a single quarter milk sample submitted to the Valio laboratory during 2012. The reason for milk sampling was detection of clinical or subclinical mastitis (elevated milk SCC) in the quarter, and the sample was taken by a visiting veterinarian or herd staff member using an aseptic technique (Hogan et al., 1999). In our study, a cow was defined as having an IMI if a quarter milk sample with DNA of some target species was detected in the PathoProof Mastitis PCR Assay. Only samples with DNA of 1 microbial species, or DNA of 2 species but 1 dominant (i.e., representing $>90 \%$ of the total target species DNA), were included in the data. Samples considered to be contaminated, with no target DNA, DNA of 2 species but no dominant species, or with 3 or more species were excluded from the data.

The proportions of all microbial species detected in the samples have been previously reported [J. Vakkamäki (University of Helsinki, Saarentaus, Finland), S. Taponen, A.-M. Heikkilä, and S. Pyörälä, unpublished data]. Microbial species selected for investigation in the pathogen-specific analyses of our study were the 6 most commonly detected species in the milk samples: 
Table 1. The number and percentages of dairy cows with IMI caused by the 6 most common pathogens in 4,173 Finnish dairy herds and the number of control cows without IMI in the same herds in 2012

\begin{tabular}{lrr}
\hline Causative agent of IMI & $\mathrm{n}$ & $\%$ \\
\hline CNS & 13,508 & 45.1 \\
Staphylococcus aureus & 7,917 & 26.4 \\
Streptococcus uberis & 2,406 & 8.0 \\
Streptococcus dysgalactiae & 2,301 & 7.7 \\
Corynebacterium bovis & 2,369 & 7.9 \\
Escherichia coli & 1,468 & 4.9 \\
Cows with IMI, total & 29,969 & 100.0 \\
Control cows & 160,176 & \\
Total & 190,145 & \\
\hline
\end{tabular}

CNS, Staph. aureus, Strep. uberis, Strep. dysgalactiae, $C$. bovis, and E. coli. These species accounted for more than $90 \%$ of the bacterial findings. Samples with other microbial species were excluded. If a cow had several milk samples sent for analysis during the year, only data for the first sample were included in the study.

The control group consisted of all IMI-free cows from the same herds as cows in the study group. Absence of IMI was determined as no milk samples sent for microbiological analysis to the Valio laboratory, no treatment records for mastitis during lactation, and no dry cow treatment. It is still possible that some control cows may have had mastitis but, as they originated from the same herds as the study cows and shared the same management, it is likely that most of them were truly IMI-free. The number of IMI-free control cows and the number of cows with IMI due to various pathogens are presented in Table 1. The data meeting the inclusion criteria for the study or control group included $67 \%$ Finnish dairy cows originating from 4,173 dairy farms, which accounted for about $46 \%$ of Finnish dairy herds in 2012 (Luke, 2016a,b). The main breeds in the original data were Nordic Red (NR), also known as Finnish Ayrshire (61.6\%), and Holstein (HOL; 36.6\%). The remainder, $1.8 \%$, included mainly Finncattle and NR or HOL crossbreds. Because the latter group was heterogeneous and small, it was excluded from the study.

Microbiological results of the milk samples analyzed in the laboratory of Valio Ltd. were merged with production and breeding index records from the recording systems. The data included information on individual cows, such as breed, parity, and annual milk yield (kg per year). Of the animal breeding indices, 3 were included: the milk yield index, udder health index (based on recorded veterinary-supervised treatments of mastitis and milk SCC), and cell count index (based only on milk SCC). The national recording systems also provided herd-specific information on milking and housing system and production type (organic vs. conventional), which were included in the study data.

\section{Statistical Analyses}

Multilevel logistic regression was used for studying herd- and cow-specific risk factors on occurrence of IMI caused by CNS, Staph. aureus, Strep. uberis, Strep. dysgalactiae, C. bovis, and E. coli. Traditional logistic regression assumes (along with other assumptions) independent responses; however, assuming that cows within a herd are independent is not meaningful. Therefore, multilevel modeling was used, which enables taking the within-herd correlation into consideration.

The multilevel logistic regression model is expressed as

$$
\begin{gathered}
\operatorname{Pr}\left(y_{i}=1\right)=\operatorname{logit}^{-1}\left[\alpha_{j(i)}+\mathrm{X}_{i} \beta\right] \\
\alpha_{j} \sim N\left(\mu_{\alpha}, \sigma_{\text {herd }}^{2}\right)
\end{gathered}
$$

where $i=1, \ldots, n$ corresponds to cows and $j=1, \ldots$, $J$ corresponds to herds. Here, $y_{i}$ is a binary outcome (IMI, no IMI); $X$ is a matrix of cow- and herd-specific predictors and $\beta_{1}, \ldots, \beta_{k}$ are the corresponding parameters; $\alpha_{j(i)}$ is a random intercept, varying with respect to herd and $j(i)$ denotes the herd of the $i$ th cow; $\alpha_{j(i)}$ is assumed to be normal with mean $\mu_{a}$ and variance $\sigma_{\text {herd }}^{2}$, which are estimated from the data. Treating the intercept $\alpha_{j(i)}$ as random instead of fixed enables within-herd correlation.

The multilevel logistic regression models of this study were performed using R ( R Core Team, 2014) and the packages Epi (Carstensen et al., 2015), lme4 (Bates et al., 2015), plyr (Wickham, 2011), and ResourceSelection (Lele et al., 2014). For model selection we investigated the Wald statistics (univariable $P$-values) for the individual model parameters, performed likelihood ratio tests between different models, and used Akaike information criterion as well. Likelihood ratio tests were also used in investigating whether model parameters were simultaneously statistically significant (multivariable $P$-values). To investigate the predictive power of the models, we calculated the receiver operating characteristic (ROC) curve, which is a plot of sensitivity as a function of $(1-$ specificity). The ROC curve essentially compares the fitted values with the actual response values. The larger the area below the ROC curve, the better the predictive power of the model. This area gets values between 0 and 1 and is called the concordance index (c index). A c index value of 0.5 states that a model has no predictive power and a value close to 1 states excellent predictive power. Concordance index was calculated for each model. We also examined the goodness of fit of each model by performing the Hosmer-Lemeshow test (HL test) with 
logit and probit links. The test assesses whether the proportion of the observed responses in certain subgroups matches the estimated response proportion. The findings from the aforementioned model examinations are reported with the estimation results. Furthermore, multicollinearity was examined by modeling each numerical explanatory variable separately with the other numerical explanatory variables. For each model, the coefficient of determination was calculated. A value above 0.90 would indicate multicollinearity. All of the models had coefficient of determination values lower than 0.1; thus, no multicollinearity was found.

The outcome variable of equation 1 is binary, either no IMI or IMI caused by the 6 specific bacterial species or group of species: CNS, Staph. aureus, Strep. uberis, Strep. dysgalactiae, C. bovis, and E. coli. Six different multilevel logistic regression models were fitted with the 6 outcome variables to indicate detection of the various species in milk samples. All models contained herd as a random effect to correct for clustering of cows within herds.

Explanatory variables for equation 1 were selected model by model based on the criteria used in the model examination. The cow-specific factors were selected from parity (numerical), breed (categorical), annual milk yield (numerical), breeding index for milk production (numerical), and breeding index for milk SCC (numerical). Out of the 2 available breeding indices for udder health, index for milk SCC was selected as having more explanatory power than the composite index for udder health. Two breed factor categories (NR, HOL) were included in the analysis. In accordance with the selection criteria, the following herd-specific factors were chosen for the models: milking system (bucket milking machine or pipeline milking, milking parlor, automatic milking) and production type (organic, conventional). Barn type was not used as an explanatory factor because it was included in the milking system variable; bucket milking machine and pipeline milking occur in tiestall systems, and milking parlor and automatic milking system (AMS) in freestall housing systems. All pairwise interactions with the categorical and numerical variables were tested and significant interactions were included in the models. In the statistical modeling, NR breed, milking parlor, and conventional production were used as the reference values for these categorical variables. The model parameters are reported with the estimation results in Table 2.

The interpretation of the coefficients in the model with a logit scale is not equivalent to the interpretation of ordinary least squares regression coefficients. The sign of $\beta$ for the explanatory variables indicates whether the corresponding variable has a positive or a negative effect on the response variable (IMI prob- ability). Another interpretation for $\beta$ based on odds ratio also exists; however, odds ratios are complicated to interpret. Thus, we preferred calculating probability estimates for interesting combinations of explanatory variable values. We also calculated a relative probability by dividing each individual estimated probability by the probability considered to be baseline probability (NR breed, parlor milking, first parity, median values of other quantitative variables).

\section{RESULTS}

Table 2 shows the parameter estimates for modeling occurrence of IMI caused by the specific pathogens. Depending on the pathogen, some or all of the following explanatory variables were associated with IMI: parity, breed, annual milk yield, breeding index for milk yield, breeding index for SCC, milking system, and type of production. Interactions terms were also present in the models except when IMI was caused by CNS or $C$. bovis (Table 2).

In each pathogen-specific model, the model parameters were simultaneously significant $(P<0.01)$. The $c$ index values of the models indicated that the models had either good or excellent predictive power (Table 2 ). The HL test, however, indicated a poor fit for both logit and probit links in every model (Table 2). The contradiction between the c index and the HL test could indicate that the fit of the models is better for a subset of cows. The examination of this phenomenon is beyond this study.

Table 3 shows some examples of the probabilities of pathogen-specific IMI for different combinations of risk factors. The probabilities are derived from the parameter estimates presented in Table 2. The categorical factors of the combination are named in the table. If the numerical factors are not in the 1st or 3rd quartile, they are fixed at their median values. The row showing the probability of IMI for a Nordic Red cow of first parity with parlor milking and numerical factors at their medians is considered the baseline. The relative probability of this baseline combination is 1 ; the relative probabilities of other combinations are proportional to the baseline (Table 3).

\section{Cow-Specific Factors Associated with IMI Caused by Specific Pathogens}

Parity was positively associated with IMI caused by the 6 specific bacterial species (i.e., the probability for IMI caused by them increased with increasing parities). The association between parity and IMI caused by Staph. aureus, Strep. dysgalactiae, and E. coli varied according to the milking system. When the causative 
PATHOGEN-SPECIFIC RISK FACTORS OF BOVINE MASTITIS

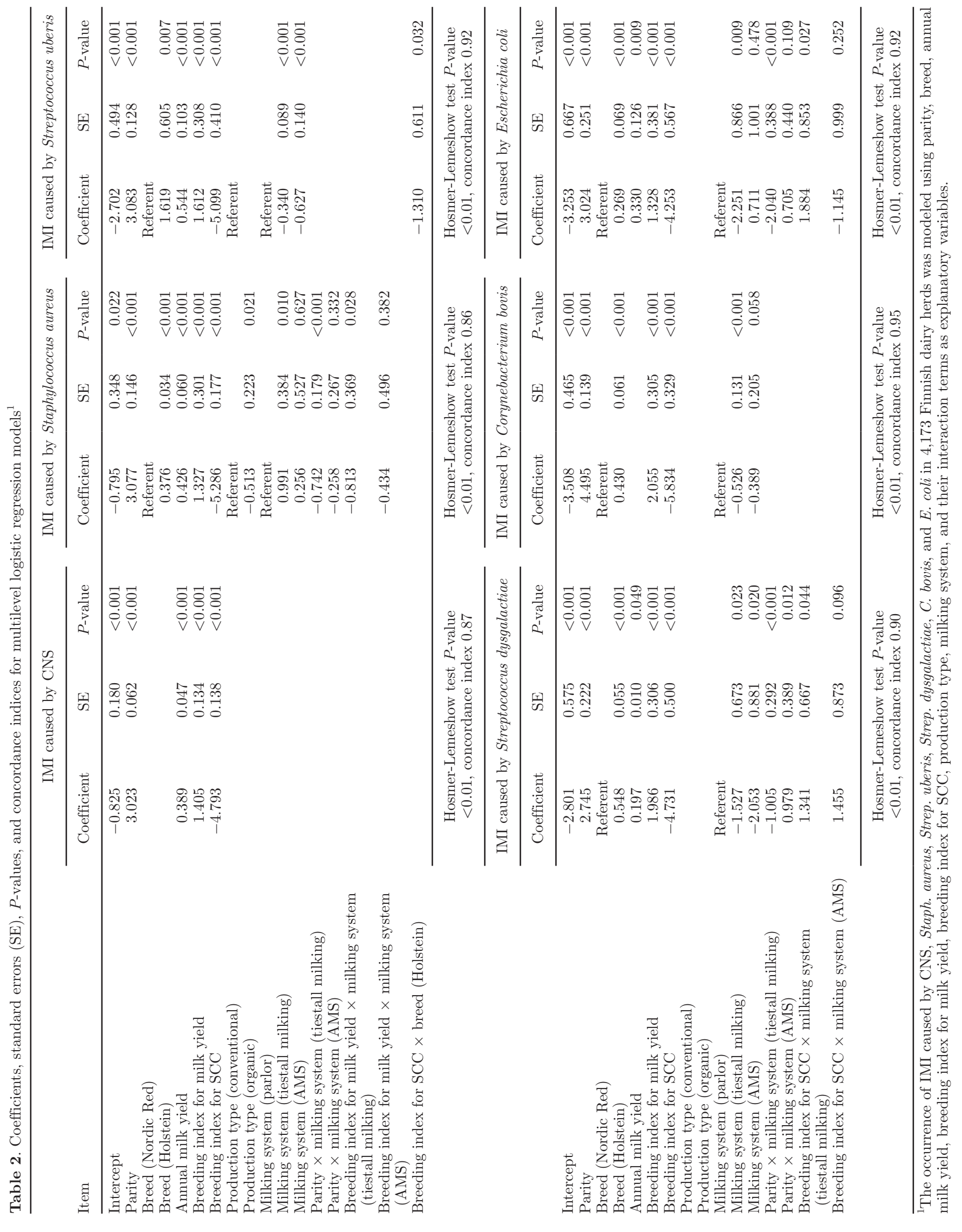




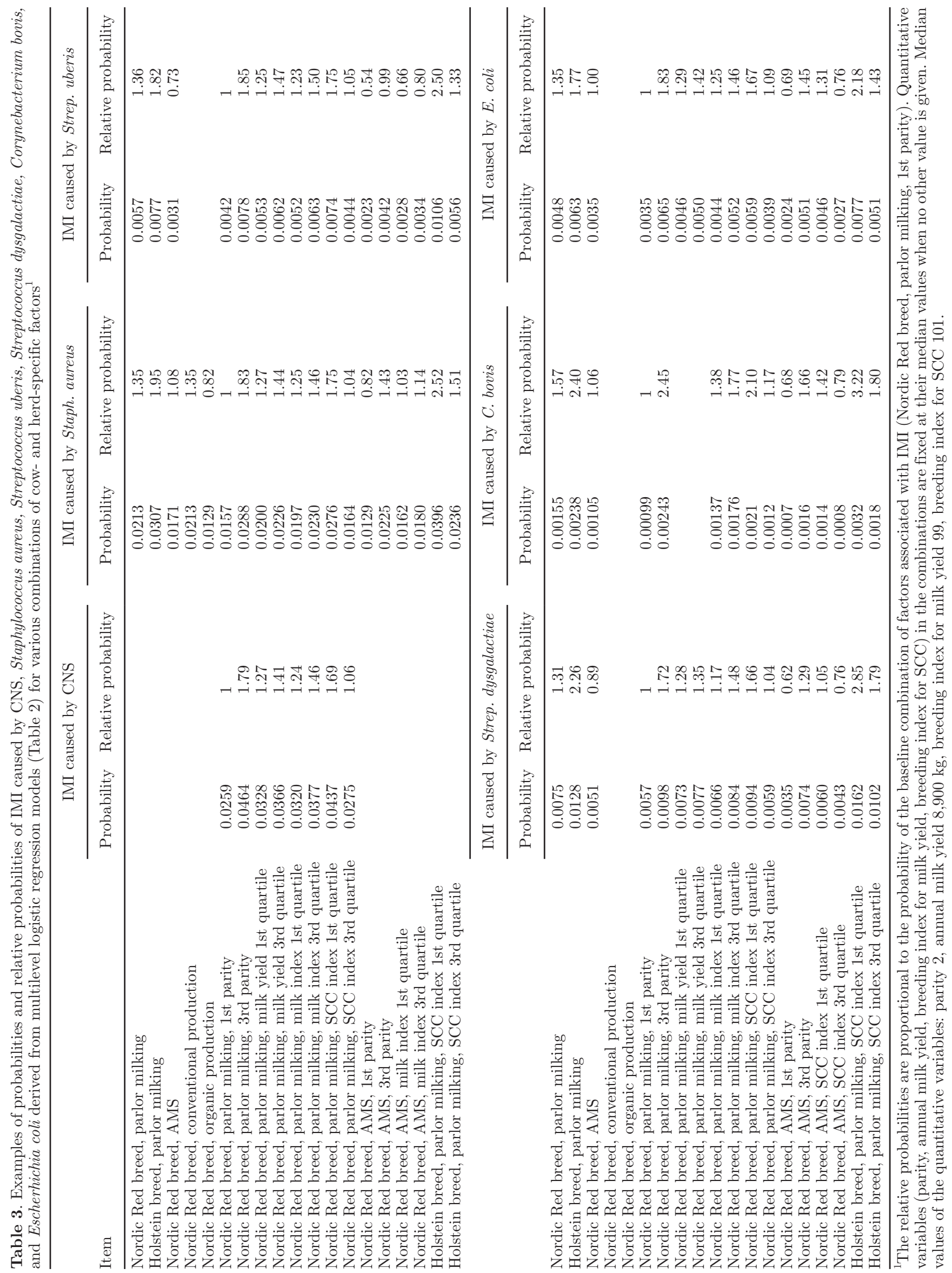


pathogen was Staph. aureus, the parity effect was the strongest in parlor milking, slightly weaker in AMS, and the weakest in tiestall milking. For IMI caused by Strep. dysgalactiae or by E. coli, the association was strongest in AMS, slightly weaker in parlor milking, and weakest in tiestall milking. In all cases, the difference was statistically significant between parlor milking and tiestall milking, but significant between parlor milking and AMS only for Strep. dysgalactiae IMI (Table 2). Breed was associated with IMI for all other bacteria except CNS; HOL cows were more likely to have IMI than NR cows (Table 2).

Higher annual milk production and better breeding index for milk production increased the probability for IMI caused by CNS, Staph. aureus, Strep. uberis, Strep. dysgalactiae, and E. coli. Probability of C. bovis IMI was positively associated with the breeding index for milk production, but not with annual milk production. The association between Staph. aureus IMI and the breeding index for milk production varied between milking systems. The effect of the index was strongest in parlor milking, slightly weaker in AMS, and the weakest in tiestall milking, and the difference between parlor milking and tiestall milking was statistically significant (Table 2).

The breeding index for milk SCC was negatively associated with IMI caused by all pathogens studied; a better breeding index for SCC decreased the occurrence of IMI. In Strep. uberis IMI, the negative effect was stronger for HOL than NR, indicating that HOL cows benefit more than NR cows from high index values for low milk SCC (Table 2).

\section{Herd-Specific Factors Associated with IMI Caused by Specific Pathogens}

The presence of IMI caused by CNS was not related to the milking system. With all other studied bacterial species an association between IMI and the milking system was established. An IMI with Strep. uberis or Strep. dysgalactiae was more prevalent in parlor milking compared with tiestall milking or AMS. An IMI caused by Staph. aureus was more likely in tiestall milking than in parlor milking, but no significant difference was found between parlor milking and AMS. An IMI caused by $C$. bovis or $E$. coli were more likely in parlor milking than in tiestall milking, but no difference was found between parlor milking and AMS (Table 2). The only association between pathogen-specific IMI and production type was for IMI due to Staph. aureus, which was less common in organic than in conventional production systems (Table 2).

\section{Probability of IMI Caused by Specific Pathogens}

The estimated probabilities in Table 3 indicate that the risk factors for CNS IMI were increasing parity and a low breeding index for milk SCC. These factors plus HOL made up a risk combination of cow-specific factors for all other pathogen-specific IMI investigated in this study. The HOL breed increased the probability of IMI caused by Strep. dysgalactiae and C. bovis most clearly, whereas higher parity increased the probability of IMI caused by $C$. bovis most and the probability of IMI caused by Strep. dysgalactiae least. The breeding index for SCC was associated most with the probability of IMI caused by $C$. bovis and, together with the effect of the breed, the probability of Strep. uberis in HOL cows. Associations between milk yield and probability of IMI, when significant, were rather similar regardless of the causative pathogen. Increase of the probability of IMI caused by $C$. bovis had the strongest association with the increase in the breeding index for milk yield (Table 3).

The difference in the probability of IMI between the milking systems was the biggest for IMI caused by Strep. uberis, AMS being associated with the lowest probability. Probability of IMI was higher in parlor milking than in AMS for every combination of the risk factors presented in Table 3.

\section{DISCUSSION}

High milk production was associated with increased susceptibility to IMI. This was evident through 2 variables in the multilevel logistic regression models. Both the annual milk production and the breeding index for milk production of the cow produced the same result; IMI is more common among high-yielding cows and those with a better breeding index for milk yield, with the exception of $C$. bovis IMI, where only the breeding index was significant. Regarding Staph. aureus, the association between IMI and breeding index for milk production was related to the milking systems, being strongest in parlor milking and weakest in tiestalls. The reasons for this remain a question, but could reflect some management factors of high-yielding cows in tiestalls that protect them from Staph. aureus IMI. The positive association between milk yield and mastitis in dairy cows has been reported previously (Heringstad et al., 2003; Koivula et al., 2005; Negussie et al., 2008; Oltenacu and Broom, 2010). An IMI caused by CNS, in particular, has been associated with high milk production; some researchers have even suggested that CNS IMI could positively affect milk production (Piepers et al., 2010, 2013). However, decreases in milk production 
due to mastitis is an established phenomenon (Seegers et al., 2003; Hertl et al., 2014; Detilleux et al., 2015). Thus, we may conclude that milk production of cows with IMI would have been even higher in the absence of IMI.

Parity was positively associated with occurrence of IMI; that is, increasing age of the cow increased the risk for IMI. This was true for all pathogens investigated and agrees with previous studies (e.g., HagnestamNielsen et al., 2009; Nyman et al., 2014). Reasons for the increased risk of mastitis with increasing parity are not completely understood, but one reason could be impairment of leukocyte functions in older cows (Mehrzad et al., 2002; Rainard and Riollet, 2006); another reason may be alterations in teat conformation with increasing age of the cow. Guarín and Ruegg (2016) reported premilking diameter of the teat apex to be a risk factor for clinical mastitis and found that it was greater in cows with parity $\geq 3$. Subsequent lactation periods may also affect conformation and depth of the udder and callosity of the teat end, increasing susceptibility to IMI (Rogers, 1993; Neijenhuis et al., 2001; Breen et al., 2009). In our study, IMI caused by CNS also increased with increasing parity, in contrast to reports where CNS were more common in first-lactation cows than in multiparous cows (Sampimon et al., 2009; Tenhagen et al., 2009). In fact, high parity and a low breeding index for milk SCC were the most important risk factors for IMI with CNS (Table 3). Tenhagen et al. (2009) showed that the proportion of CNS isolated in milk samples from cows with clinical mastitis within 1 wk after parturition was over $30 \%$ in primiparous cows but $20 \%$ or less in multiparous cows. Later in the lactation, the respective proportions were around $10 \%$ in primiparous and $15 \%$ in multiparous cows. The effect of parity varied according to the milking system; association between parity and IMI was strongest in parlor milking for Staph. aureus IMI, but strongest in AMS for Strep. dysgalactiae and E. coli IMI. In tiestall milking the effect of parity was weakest for all of bacteria. This could imply that the negative effect of increasing parity of the cow can in tiestalls be somehow compensated by different management of the older cows or by careful selecting of cows for culling.

Holstein cows were more prone to IMI than NR, in agreement with an earlier Finnish study and a study comparing Swedish HOL and Swedish Red cows (Heikkilä et al., 2012; Nyman et al., 2014). In our study, breed was a significant factor for IMI, with the exception of CNS IMI. The difference favored the NR breed in all models. As the interaction term between breed and annual milk yield was nonsignificant, reasons other than just higher milk production must explain the difference between HOL and NR. One possible explana- tion could be the generally better milkability of the HOL breed (i.e., quicker milk release and larger minute flow; Carlström et al., 2013). These characteristics may be associated with milk leaking tendency and a looser teat canal, which predispose the udder to bacterial invasion via the teat opening. The HOL breed particularly increased the probability of IMI caused by Strep. dysgalactiae and C. bovis, which could be related to udder and teat conformation.

Cows with a better breeding index for milk SCC had significantly less IMI. This confirms that including SCC in the breeding index of dairy cows improves udder health, as reported by Koivula et al. (2005). The association between IMI and the breeding index for milk SCC was stronger than the association between IMI and the composite index for udder health. Therefore, the index for SCC was selected for multilevel logistic regression models. With regard to Strep. uberis IMI, the effect of breeding for low SCC was stronger in HOL than in NR, which could be associated with breed-related predisposing factors for this environmental pathogen.

Milking system, which was found to affect the probability of IMI, is intimately associated with the type of housing. Parlor milking in Finland is mainly used in older free-housing barns, whereas new free-housing barns most often have AMS. Although Finnish tiestall barns are generally old, they did not increase the probability of IMI caused by the pathogens studied except Staph. aureus. Free housing with parlor milking significantly increased the probability of IMI due to Strep. uberis and Strep. dysgalactiae compared with tiestall barns and new barns with free housing and AMS. The differences between milking systems were largest for Strep. uberis IMI. Escherichia coli and C. bovis IMI were more probable in freestalls with parlor milking compared with tiestalls. Environmental conditions in freestalls differ from those in tiestalls and may favor different bacterial species. Tiestalls are usually fairly dry, whereas the floors of the walking areas of freestalls are often wet, depending on the design of the alleys and the effectiveness of the manure removal system. It is possible that housing conditions in older free-housing barns are inferior to those in both new large barns with AMS and old tiestall barns. A Finnish study by Hovinen et al. (2009) reported that cows in tiestalls had a lower milk SCC than cows in loose-housing barns. Housing conditions and cow and cubicle cleanliness have been related to incidence of clinical mastitis due to E. coli in previous studies (Schukken et al., 1991; Barkema et al., 1999; Breen et al., 2009). In herds scored dirty based on proportion of dirty udders, the incidence rate of clinical mastitis, and especially of clinical E. coli mastitis, was higher than in herds scored clean (Verbeke et al., 2014). In 2 studies, the proportion of clinical mastitis due to 
E. coli was significantly higher for cows in freestalls than for those in tiestalls (Olde Riekerink et al., 2008; Ericsson Unnerstad et al., 2009).

One tool for mastitis control, which is easier to establish in tiestalls than in freestalls, is adapting milking order for cows with different udder health status to prevent contagious mastitis. Staphylococcus aureus is a contagious udder pathogen and well-known cause of chronic mastitis (Barkema et al., 2006). However, in our study, the probability of IMI caused by Staph. aureus was greatest in tiestalls. In agreement with our study, in 2 earlier studies, clinical mastitis caused by Staph. aureus was associated with tiestalls (Olde Riekerink et al., 2008; Ericsson-Unnerstad et al., 2009). In large freestall systems, grouping of cows with different health status would also be possible, but Finnish freestalls are still relatively small for that (Hovinen et al., 2013). In their review of the relationship between management factors and herd SCC, Dufour et al. (2011) concluded that freestall housing with sand bedding was best for udder health. Comparison of our results on the effect of barn types with earlier studies is difficult because conditions in different countries are not comparable.

Automatic milking, in general, did not increase the probability of IMI by any of the studied pathogens; this was somewhat unexpected, as average cow and bulk milk SCC are generally higher for automatically milked herds (Dufour et al., 2011; Hovinen and Pyörälä, 2011). Automatic milking in Finland has increased rapidly since installation of the first 2 milking robots in 2000 (Hovinen et al., 2009). At the end of 2015, the number of dairy herds with AMS was 950 and their proportion of all dairy herds was about 13\%. (E. Manninen, Valio Ltd., Helsinki, Finland; personal communication). The differences in the probability for IMI between AMS and parlor milking seen here likely depended on several factors. First, Finnish barns with AMS are more upto-date than barns with parlor milking, of which the majority originate from the 1980s and 1990s and represent the space allocation and technical standards of that time. Hygienic conditions and, for example, design of the lying cubicles, are better in new barns. Second, when changing from an old barn to a new barn with AMS, cows to be kept in the herd are selected. Cows suited to AMS remain but cows with poor udder conformation and those with chronic IMI, especially Staph. aureus IMI, are culled (Dufour et al., 2011). Moreover, AMS milks the udder on a quarter basis, which may have a positive effect on udder health (Jacobs and Siegford, 2012). The increased milking frequency in AMS compared with conventional milking has generally been associated with less mastitis (Hovinen and Pyörälä, 2011). In our study AMS was associated with the lowest probability for Strep. uberis IMI, which is considered to be mainly of environmental origin (Zadoks et al., 2003). The reason for lower incidence of Strep. uberis in automatic milking may be better environmental conditions in the new barns compared with the old freestall barns.

Coagulase-negative staphylococci IMI was not associated with milking system, which supports the current understanding of CNS being common residents of bovine teat skin and canal (De Visscher et al., 2014). Results from earlier studies agree with ours: an increased prevalence of CNS IMI is associated with several cow and herd level risk factors, but not with any specific milking or housing system (Sampimon et al., 2009; Piepers et al., 2011). For the other minor pathogen, $C$. bovis, an association with milking system was found: the probability for $C$. bovis IMI was higher in parlor milking than in tiestalls. No difference was found between parlor milking and AMS. Corynebacterium bovis is a contagious pathogen that commonly contaminates teats and spreads among cows (Honkanen-Buzalski et al., 1984). Finding less C. bovis in tiestalls may be related to better milking hygiene and individual care of the cows in smaller herds.

The only association established between IMI and organic production was the probability of IMI caused by Staph. aureus being smaller for cows in organic than in conventional herds. Levison et al. (2016) made a similar observation on Canadian dairy farms. This phenomenon is difficult to explain by factors other than the more intensive culling of cows with Staph. aureus IMI on organic farms because of the reluctance to use antibiotics. An indication of this was evident in our data, in which mastitis as a cause of culling was recorded for $24 \%$ of cases in conventional herds and for $31 \%$ of cases in organic herds (data not shown). Levison et al. (2016) also concluded that organic management is generally associated with reduced incidence of clinical mastitis. Our results do not support this conclusion.

\section{CONCLUSIONS}

We showed that breeding for improved udder health has been successful in reducing the incidence of IMI caused by the most common pathogens in Finland, and its emphasis should thus be maintained in cattle breeding. The balance between breeding for improved udder health and milk production is particularly important because high milk yield is a risk factor for IMI caused by all pathogens included the study except $C$. bovis. In the Finnish dairy sector, the importance of other measures to control IMI will also grow in the future as the proportion of the more susceptible Holstein breed increases whereas that of the Nordic Red breed decreases. Dairy farmers have to search for an optimal solution between the 2 current conflicting goals of extending the 
production life of dairy cows and decreasing the occurrence of IMI, because more parities mean more IMI; this is valid regardless of the pathogen, but particularly important for IMI caused by C. bovis. Attention should be paid to hygiene and cleanliness of the environment and the cows to manage IMI in old freestall barns, which were shown to represent a risk, particularly for IMI caused by Strep. uberis and Strep. dysgalactiae. In tiestalls, special attention should be paid to IMI caused by Staph. aureus to manage it successfully. The increasing proportion of AMS is not a reason for concern; contrary to our expectations, AMS was not a significant risk factor for any of the pathogen-specific IMI that we investigated.

\section{ACKNOWLEDGMENTS}

Financial support from Walter Ehrström Foundation (Helsinki, Finland) and the Ministry of Agriculture and Forestry of Finland (Helsinki) is gratefully acknowledged. We also thank Valio Ltd. (Helsinki, Finland) for financing this study and for allowing us to use their bacteriological database, and ProAgria (Vantaa, Finland) for providing us data from the Finnish dairy herd-recording systems.

\section{REFERENCES}

Barkema, H. W., Y. H. Schukken, T. J. G. M. Lam, M. L. Beiboer, G. Benedictus, and A. Brand. 1999. Management practices associated with the incidence rate of clinical mastitis. J. Dairy Sci. 82:1643-1654.

Barkema, H. W., Y. H. Schukken, and R. N. Zadoks. 2006. Invited review: The role of cow, pathogen, and treatment regimen in the therapeutic success of bovine Staphylococcus aureus mastitis. J. Dairy Sci. 89:1877-1895.

Bates, D., M. Maechler, B. Bolker, and S. Walker. 2015. Ime4: Linear mixed-effects models using Eigen and S4. R package version 1.1-9. Accessed Apr. 1, 2016. https://cran.r-project.org/web/packages/ lme4/index.html.

Bradley, A. J., K. A. Leach, J. E. Breen, L. E. Green, and M. J. Green. 2007. Survey of the incidence and aetiology of mastitis on dairy farms in England and Wales. Vet. Rec. 160:253-257.

Breen, J. E., M. J. Green, and A. J. Bradley. 2009. Quarter and cow risk factors associated with the occurrence of clinical mastitis in dairy cows in the United Kingdom. J. Dairy Sci. 92:2551-2561. http://dx.doi.org/10.3168/jds.2008-1369.

Carlström, C., G. Pettersson, K. Johansson, E. Strandberg, H. Stålhammar, and J. Philipsson. 2013. Feasibility of using automatic milking system data from commercial herds for genetic analysis of milkability. J. Dairy Sci. 96:5324-5332. http://dx.doi.org/10.3168/ jds.2012-6221.

Carstensen, B., M. Plummer, E. Laara, and M. Hills. 2015. Epi: A Package for Statistical Analysis in Epidemiology. R package version 1.1.71. Accessed Apr. 1, 2016. http://CRAN.R-project.org/ package $=$ Epi.

De Visscher, A., K. Supré, F. Haesebrouck, R. N. Zadoks, V. Piessens, E. Van Coillie, S. Piepers, and S. De Vliegher. 2014. Further evidence for the existence of environmental and host-associated species of coagulase-negative staphylococci in dairy cattle. Vet. Microbiol. 172:466-474. http://dx.doi.org/10.1016/j.vetmic.2014.06.011.
Detilleux, J., J. P. Kastelicb, and H. W. Barkema. 2015. Mediation analysis to estimate direct and indirect milk losses due to clinical mastitis in dairy cattle. Prev. Vet. Med. 118:449-456. http:// dx.doi.org/10.1016/j.prevetmed.2015.01.009.

Dufour, S., A. Fréchette, H. W. Barkema, A. Mussell, and D. T. Scholl. 2011. Invited review: Effect of udder health management practices on herd somatic cell count. J. Dairy Sci. 94:563-579. http://dx.doi. org/10.3168/jds.2010-3715.

Ericsson Unnerstad, H., A. Lindberg, K. Persson Waller, T. Ekman, K. Artursson, M. Nilsson-Öst, and B. Bengtsson. 2009. Microbial aetiology of acute clinical mastitis and agent-specific risk factors. Vet. Microbiol. 137:90-97. http://dx.doi.org/10.1016/j. vetmic.2008.12.005

Guarín, J. F., and P. L. Ruegg. 2016. Short communication: Pre- and postmilking anatomical characteristics of teats and their associations with risk of clinical mastitis in dairy cows. J. Dairy Sci. 99:1-7. http://dx.doi.org/10.3168/jds.2015-10093.

Hagnestam-Nielsen, C., U. Emanuelson, B. Berglund, and E. Strandberg. 2009. Relationship between somatic cell count and milk yield in different stages of lactation. J. Dairy Sci. 92:3124-3133. http:// dx.doi.org/10.3168/jds.2008-1719.

Halasa, T., K. Huijps, O. Østerås, and H. Hogeveen. 2007. Economic effects of bovine mastitis and mastitis management: A review. Vet. Q. 29:18-31.

Heikkilä, A.-M., J. I. Nousiainen, and S. Pyörälä. 2012. Costs of clinical mastitis with special reference to premature culling. J. Dairy Sci. 95:139-150. http://dx.doi.org/10.3168/jds.2011-4321.

Heringstad, B., G. Klemetsdal, and T. Steine. 2003. Selection responses for clinical mastitis and protein yield in two Norwegian dairy cattle selection experiments. J. Dairy Sci. 86:2990-2999. http:// dx.doi.org/10.3168/jds.S0022-0302(03)73897-1.

Hertl, J. A., Y. H. Schukken, F. L. Welcome, L. W. Tauer, and Y. T. Gröhn. 2014. Pathogen-specific effects on milk yield in repeated clinical mastitis episodes in Holstein dairy cows. J. Dairy Sci. 97:1465-1480. http://dx.doi.org/10.3168/jds.2013-7266.

Hogan, J. S., R. N. González, R. J. Harmon, S. C. Nickerson, S. P. Oliver, J. W. Pankey, and K. L. Smith. 1999. Laboratory Handbook on Bovine Mastitis. Rev. ed. National Mastitis Council, Madison, WI

Honkanen-Buzalski, T., T. K. Griffin, and F. H. Dodd. 1984. Observations on Corynebacterium bovis infection of the mammary gland I. Natural infection. J. Dairy Res. 51:371-378.

Hovinen, M., and S. Pyörälä. 2011. Invited review: Udder health of dairy cows in automatic milking. J. Dairy Sci. 94:547-562. http:// dx.doi.org/10.3168/jds.2010-3556.

Hovinen, M., M. D. Rasmussen, and S. Pyörälä. 2009. Udder health of cows changing from tie stalls or free stalls with conventional milking to free stalls with either conventional or automatic milking. J Dairy Sci. 92:3696-3703. http://dx.doi.org/10.3168/jds.2008-1962.

Hovinen, M., K. Sarjokari, M. Norring, L. Seppä-Lassila, and T. Soveri. 2013. Udder health in modern dairy farms-Associations with management and grouping of cows. The 28th NKVet Symposium: Mastitis - New Knowledge on Diagnostics and Control on Modern Dairy Farms. May 13-14, 2013, in Reykjavik, Iceland. Accessed Mar. 3, 2016. http://www.nkvet.org/user_files/Hovinen.pdf.

Jacobs, J. A., and J. M. Siegford. 2012. Invited review: The impact of automatic milking systems on dairy cow management, behavior, health, and welfare. J. Dairy Sci. 95:2227-2247. http://dx.doi org/10.3168/jds.2011-4943.

Koivula, M., E. A. Mäntysaari, E. Negussie, and T. Serenius. 2005. Genetic and phenotypic relationships among milk yield and somatic cell count before and after clinical mastitis. J. Dairy Sci. 88:827833. http://dx.doi.org/10.3168/jds.S0022-0302(05)72747-8.

Koivula, M., A. Pitkälä, S. Pyörälä, and E. A. Mäntysaari. 2007. Distribution of bacteria and seasonal and regional effects in a new database for mastitis pathogens in Finland. Acta Agric. Scand. A Anim. Sci. 57:89-96. http://dx.doi.org/10.1080/09064700701488941.

Lele, S. R., J. M. Keim, and P. Solymos. 2014. ResourceSelection: Resource Selection (Probability) Functions for Use-Availability Data. R package version 0.2-4. Accessed Apr. 1, 2016. http:// CRAN.R-project.org/package= ResourceSelection 
Levison, L. J., E. K. Miller-Cushon, A. L. Tucker, R. Bergeron, K. E. Leslie, H. W. Barkema, and T. J. DeVries. 2016. Incidence rate of pathogen-specific clinical mastitis on conventional and organic Canadian dairy farms. J. Dairy Sci. 99:1341-1350. http://dx.doi. org/10.3168/jds.2015-9809.

Luke. 2016a. The structural development of agriculture. Natural Resources Institute Finland, Economydoctor. Accessed Jun. 27, 2016. https://portal.mtt.fi/portal/page/portal/economydoctor/ structural_development/timeline/production_types.

Luke. 2016b. Number of livestock. Natural Resources Institute Finland, Statistics database, Accessed Jun. 27, 2016. http://stat.luke. fi/en/uusi-etusivu.

McDougall, S. 1998. Efficacy of two antibiotic treatments in curing clinical and subclinical mastitis in lactating dairy cows. N. Z. Vet. J. 46:226-232.

Mehrzad, J., L. Duchateau, S. Pyörälä, and C. Burvenich. 2002. Blood and milk neutrophil chemiluminescence and viability in primiparous and pluriparous dairy cows during late pregnancy, around parturition and early lactation. J. Dairy Sci. 85:3268-3276. http:// dx.doi.org/10.3168/jds.S0022-0302(02)74415-9.

Milne, M. H., D. C. Barrett, J. L. Fitzpatrick, and A. M. Biggs. 2002. Prevalence and aetiology of clinical mastitis on dairy farms in Devon. Vet. Rec. 151:241-243. http://dx.doi.org/10.1136/vr.151.8.241.

Negussie, E., I. Strandén, and E. A. Mäntysaari. 2008. Genetic association of clinical mastitis with test-day somatic cell score and milk yield during first lactation of Finnish Ayrshire cows. J. Dairy Sci. 91:1189-1197. http://dx.doi.org/10.3168/jds.2007-0510.

Neijenhuis, F., H. W. Barkema, H. Hogeveen, and J. P. T. M. Noordhuizen. 2001. Relationship between teat-end callosity and occurrence of clinical mastitis. J. Dairy Sci. 84:2664-2672.

Nyman, A.-K., K. Persson Waller, T. W. Bennedsgaard, T. Larsen, and U. Emanuelson. 2014. Associations of udder-health indicators with cow factors and with intramammary infection in dairy cows. J. Dairy Sci. 97:5459-5473. http://dx.doi.org/10.3168/jds.20137885 .

Olde Riekerink, R. G., H. W. Barkema, D. F. Kelton, and D. T. Scholl 2008. Incidence rate of clinical mastitis on Canadian dairy farms. J. Dairy Sci. 91:1366-1377. http://dx.doi.org/10.3168/jds.20070757.

Oltenacu, P. A., and D. M. Broom. 2010. The impact of genetic selection for increased milk yield on the welfare of dairy cows. Anim. Welf. 19:39-49.

Peeler, E. J., M. J. Green, J. L. Fitzpatrick, K. L. Morgan, and L. E. Green. 2000. Risk factors associated with clinical mastitis in low somatic cell count British dairy herds. J. Dairy Sci. 83:2464-2472.

Piepers, S., G. Opsomer, H. W. Barkema, A. de Kruif, and S. De Vliegher. 2010. Heifers infected with coagulase-negative staphylococci in early lactation have fewer cases of clinical mastitis and higher milk production in their first lactation than noninfected heifers. J. Dairy Sci. 93:2014-2024. http://dx.doi.org/10.3168/ jds.2009-2897.

Piepers, S., K. Peeters, G. Opsomer, H. W. Barkema, K. Frankena, and S. De Vliegher. 2011. Pathogen group specific risk factors at herd, heifer and quarter levels for intramammary infections in early lactating dairy heifers. Prev. Vet. Med. 99:91-101. http:// dx.doi.org/10.1016/j.prevetmed.2011.02.010.

Piepers, S., Y. H. Schukken, P. Passchyn, and S. De Vliegher. 2013. The effect of intramammary infection with coagulase-negative staphylococci in early lactating heifers on milk yield throughout first lactation revisited. J. Dairy Sci. 96:5095-5105. http://dx.doi org/10.3168/jds.2013-6644.

ProAgria. 2016. Results of the Finnish dairy herd recording system 2015. (In Finnish). Accessed Apr. 5, 2016. https://www.proagria. fi/sites/default/files/attachment/lypsykarjan_tuotosseurannan_ tulokset_2015.pdf.

R Core Team. 2014. R: A language and environment for statistical computing. R Foundation for Statistical Computing, Vienna, Austria. Accessed Apr. 1, 2016. http://www.R-project.org/.

Rainard, P., and C. Riollet. 2006. Innate immunity of the bovine mammary gland. Vet. Res. 37:369-400. http://dx.doi.org/10.1051/ vetres:2006007.

Reksen, O.. L. Sølverod, A. J. Branscum, and O. Østerås. 2006. Relationships between milk culture results and treatment for clinical mastitis or culling in Norwegian dairy cattle. J. Dairy Sci. 89:29282937. http://dx.doi.org/10.3168/jds.S0022-0302(06)72565-6.

Rogers, G. W. 1993. Index selection using milk yield, somatic cell score, udder depth, teat placement, and foot angle. J. Dairy Sci. 76:664-670.

Sampimon, O. C., H. W. Barkema, I. M. G. A. Berends, J. Sol, and T. J. G. M. Lam. 2009. Prevalence and herd-level risk factors for intramammary infection with coagulase-negative staphylococci in Dutch dairy herds. Vet. Microbiol. 134:37-44. http://dx.doi. org/10.1016/j.vetmic.2008.09.010.

Santman-Berends, I. M. G. A., T. J. G. M. Lam, J. Keurentjes, and G. van Schaik. 2015. An estimation of the clinical mastitis incidence per 100 cows per year based on routinely collected herd data. J. Dairy Sci. 98:6965-6977. http://dx.doi.org/10.3168/jds.2015-9642.

Schukken, Y. H., F. J. Grommers, D. van de Geer, H. N. Erb, and A. Brand. 1991. Risk factors for clinical mastitis in herds with a low bulk milk somatic cell count. 2. Risk factors for Escherichia coli and Staphylococcus aureus. J. Dairy Sci. 74:826-832.

Seegers, H., C. Fourichon, and F. Beaudeau. 2003. Review article: Production effects related to mastitis and mastitis economics in dairy cattle herds. Vet. Res. 34:475-491. http://dx.doi. org/10.1051/vetres:2003027.

Tenhagen, B.-A., I. Hansen, A. Reinecke, and W. Heuwieser. 2009 Prevalence of pathogens in milk samples of dairy cows with clinical mastitis and in heifers at first parturition. J. Dairy Res. 76:179187. http://dx.doi.org/10.1017/S0022029908003786.

van den Borne, B. H. P., G. van Schaik, T. J. G. M. Lam, and M. Nielen. 2010. Variation in herd level mastitis indicators between primiand multiparae in Dutch dairy herds. Prev. Vet. Med. 96:49-55. http://dx.doi.org/10.1016/j.prevetmed.2010.05.010.

Verbeke, J., S. Piepers, K. Supré, and S. De Vliegher. 2014. Pathogenspecific incidence rate of clinical mastitis in Flemish dairy herds, severity, and association with herd hygiene. J. Dairy Sci. 97:69266934. http://dx.doi.org/10.3168/jds.2014-8173.

Wickham, H. 2011. The split-apply-combine strategy for data analysis. J. Stat. Softw. 40:1-29. http://dx.doi.org/10.18637/jss.v040.i01.

Zadoks, R. N., H. G. Allore, H. W. Barkema, O. C. Sampimon, G. J. Wellenberg, Y. T. Gröhn, and Y. H. Schukken. 2001. Cow- and quarter-level risk factors for Streptococcus uberis and Staphylococcus aureus mastitis. J. Dairy Sci. 84:2649-2663.

Zadoks, R. N., B. E. Gillespie, H. W. Barkema, O. C. Sampimon, S P. Oliver, and Y. H. Schukken. 2003. Clinical, epidemiological and molecular characteristics of Streptococcus uberis infections in dairy herds. Epidemiol. Infect. 130:335-349. 